\title{
The Effect of Hospital Image and Service Quality on Customer Loyalty Through Customer Satisfaction
}

\author{
Susi Ardiani ${ }^{1, *}$, Sarikadarwati ${ }^{1}$, Henny Yulsiati $^{1}$, Sandrayati $^{1}$ \\ ${ }^{I}$ Department Accounting Polytechnic of Sriwijaya \\ *Corresponding author Email: susiardiani12@gmail.com
}

\begin{abstract}
The purpose of the research is to improve the Human Resources that build character as a concept of thought towards technology that is increasingly sophisticated. Where this also develops the hospital payment stage easily namely BPJS and the specific target to be achieved from this research is to analyze the Influence of Hospital Image and Service Quality on Customer Loyalty Through Customer Satisfaction as Intervening Variables in Siti Khadijah Hospital, Palembang. The method used in achieving the target is descriptive and verification analysis method using the path analysis method for the first Hypothesis and the second Hypothesis is done by residual test. The result of research is based on the analysis and discussion, the following conclusions can be drawn There is a significant influence between the dimensions of the hospital's image on customer satisfaction, There is a significant influence on service quality on customer satisfaction, there is a significant influence between customer satisfaction variables on customer loyalty, There is a significant influence between hospital image variables on customer loyalty, There is a significant influence between service quality variables on customer loyalty at the Siti Khadijah Islamic Hospital in Palembang.

Keywords: hospital image, service quality, loyalty, satisfaction
\end{abstract}

\section{INTRODUCTION}

The hospital is one of the institutions engaged in the field of health services which provides services to the community. Health services are now included in the main health services industry where every hospital is fully responsible to the recipients of health services. Along with the development of the hospital, until now there has been competition between hospitals, ranging from incessantly improving facilities, quality, and loyalty so that the impact of satisfaction to the patient itself.

Providing the best service for patients is a demand of health service providers. Those who need health services will definitely look for good health service providers and can provide satisfaction for them [1].

Social security is a human right that is protected both internationally (Universal Declaration of Human Rights) and nationally. The national social security system law explains that in the framework of implementing the provisions on the right to social security as a human right as contained in article $28 \mathrm{H}$ paragraph (3) of the 1945 Constitution: every person has the right to social security which enables his full development as dignified humans. Thus the right to social security is a constitutional right for all Indonesian people that must be fulfilled by the state.

Image is a valuable intangible asset of a company. A positive image allows a company to gain a reputation value and competitive advantage [2]. A good image will increase customer satisfaction, service quality, loyalty, and repurchase intentions [3] in [4]. A good image will be able to increase the success of a company and vice versa a bad image will worsen the stability of a company. Barsasella [5] argues that companies that have a good image or reputation will encourage consumers to buy the products offered, enhance competitiveness, encourage employee morale, and increase customer loyalty. The image of the hospital affects the attitude and behavior of patients towards the hospital. Thus, understanding the relationship between the image of the hospital and its influence on patient intentions is needed.

The success of a company shapes the image of society, influenced by several factors such as company history, the completeness of facilities and infrastructure, and success in providing services to patients. The image appears based on knowledge and information received by a person against an object. If the information is good, it will create a positive image, but vice versa if the information received is bad, it will cause a negative image. Information obtained for example about how the services provided by the hospital.

\section{LITERATURE REVIEW}

\subsection{Customer loyalty}

According to Griffin [6] loyalty is a psychological condition (attitudinal and behavioral) related to attitudes toward products, consumers will form beliefs, determine whether they like it or not, and decide whether they want to buy a product. The greater the customer's intention to repurchase or the intention to recommend a service company gives an indication that the service company has a bright business in the future. So this attitude dimension is a good indication for measuring customer loyalty. 


\subsection{Service Satisfaction}

Consumer satisfaction is the level of feeling in which someone states the results of the comparison of the performance of the service product received with expected, [7]. Meanwhile, according to Kotler, quoted again by [8] consumer satisfaction is the level of one's feelings after comparing the performance (or results) that he perceives compared to his expectations.

If customers say comfort is value, then the satisfaction they feel will occur if the customer gets comfort when using a product or service. If the customer says the low price is value, the satisfaction they feel will occur if the customer gets a competitive price.

\subsection{Service quality}

Quality of products and services is defined as a tool used to meet the desires and expectations of customers resulting from the production of goods or services, marketing carried out by the company and the maintenance of the product or service [9]. Whereas according to [6] service is any action or activity that can be offered by one party to another party, basically intangible and does not result in any ownership.

Goods or services are said to be of quality when the goods and services can be used to meet or exceed customer expectations. These customer expectations can be explained on the quality dimension. Customer expectations can be explained through quality attributes or things that are often called quality dimensions

\subsection{Hospital Image}

Image is a person's beliefs, ideas and impressions of something ". For a company, a good image is absolutely necessary. So important is the meaning of the image itself that the company is willing to pay extra money and energy to achieve it. Image is a set of beliefs, ideas, and messages that someone has towards an object [10]. Image is the main goal and at the same time is a reputation and achievement to be achieved by public relations. Nevertheless understanding of the image itself is abstract (intangible) and cannot be measured

The nation of image is the public perception of the company or its products [6]. The image is influenced by many factors outside the company's control. Image is a company that includes the company's good name, reputation or expertise is a factor that often influences the decisions of buyers and the service sector compared to the product sector.

\section{RESEARCH METHODOLOGY}

This study aims to determine the effect of hospital image and service quality on customer loyalty through customer satisfaction as an intervening variable. In this study the method used is a survey method, namely by using a questionnaire as a primary data collection tool to take several samples from the study population. The population used is patients who use health services in hospitals.

\subsection{Population and Sample}

The object of this research is the behavior of the respondents which is manifested in patients at Siti Khadijah Islamic Hospital between three constructs namely BPJS Health service quality, BPJS Health patient loyalty, and BPJS Health patient satisfaction.

The selection of sampling techniques is intended to provide an overview of the existing population. The population taken was 90 patients (bed capacity in the hospital). The first stage, namely purposive sampling, is a technique for determining samples with certain considerations. The sample criteria in this study are:

1. Inpatients: The number of BPJS patients inpatient Health at the Islamic Hospital of Siti Khadijah, Palembang City at the time of patients who were hospitalized in the period July-August 2019.

2. Outpatients: Number of BPJS Patients Outpatient Health Siti Khadijah Hospital, Palembang City at the time of patients who were hospitalized in the period July-August 2019.

\subsection{Data Analysis Method}

The data analysis method used in this study is path analysis for the first hypothesis. Path analysis as follows:

$\mathrm{X}_{4} \quad=$ patient loyalty

$\mathrm{X}_{1}=$ Hospital Image

$\mathrm{X}_{2}=$ Service Quality

$\mathrm{X}_{3}=$ patient satisfaction

$\mathrm{P}=$ Path coefficient calculated from the value of Standardized Coefficient (beta)

$\varepsilon=$ Number of unexplained Variance

\subsection{Research Design}

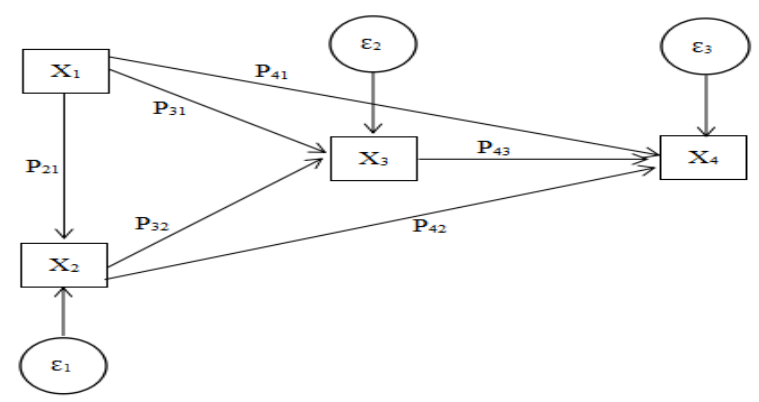

Figure 1 Conceptual framework 
The effects of $X_{1}$ and $X_{2}$ on $X_{3}$ and from $X_{3}$ to $X_{4}$ are called direct effects, while those from $X_{1}$ to $X_{4}$ through $X_{3}$ and $X_{2}$ to $X_{4}$ through $X_{3}$ are called indirect effects). Other variables that cannot be described (cannot be measured) are shown by $\varepsilon_{1}, \varepsilon_{2}$, and $\varepsilon_{3}$. To more easily formulate the problem of the model, which are:

1. There is a direct influence of $X_{1}$ to $X_{3}$

2. There is a direct influence of $X_{1}$ to $X_{4}$

3. There is a direct influence of $X_{1}$ to $X_{2}$

4. There is a direct influence of $X_{2}$ to $X_{3}$

5. There is a direct influence of $X_{2}$ to $X_{4}$

6. There is a direct influence of $X_{3}$ to $X_{4}$

7. There is an indirect effect of $X_{1}$ on $X_{4}$ through $X_{3}$

8. There is an indirect effect of $\mathrm{X}_{2}$ on $\mathrm{X}_{4}$ through $\mathrm{X}_{3}$

The structural equation that can be made is as follows.

$\mathrm{X}_{2}=\mathrm{P}_{21} \mathrm{X}_{1}+\varepsilon_{1}$

$X_{3}=P_{31} X_{1}+P_{32} X_{2}+\varepsilon_{2}$

$X_{4}=P_{41} X_{1}+P_{42} X_{2}+P_{43} X_{3}+\varepsilon_{3}$

\section{RESULTS AND DISCUSSION}

There is a significant influence between the dimensions of the hospital's image on customer satisfaction at the Siti Khadijah Islamic Hospital in Palembang. This means that the better the image of the hospital in the minds of patients, the higher patient satisfaction.

Based on the results of the study, it is known that there are still some respondents with an assessment of the image of the hospital and low quality of service. Therefore, the Islamic Hospital of Siti Khadijah Palembang is advised to be communicative and always interact with patients, good quality of service will create loyalty and warmth in the eyes of consumers, whether or not the quality of service of a service is very relative in nature. Specifically, each consumer is aware of the relative relationship between service quality and their level of expectation about a service to be used [11]. Furthermore, the quota of the quality of services provided can be compared with the experience and expectations of consumers, so that the quality of service can be accepted [12]. Therefore, services need to be improved. Because this hospital is a public hospital, responsiveness is very important in improving the quality of services, especially in hospital staff, so there is a great desire and interest from all employees to act quickly in helping patients. Every complaint submitted by patients to the hospital is immediately responded so that no patients are disappointed, so that it can create customer loyalty. A good image will increase or close the perceived lack of service by consumers, on the contrary, if a bad image will further worsen the services felt by consumers [6], [11] and [12]. Thus it is clear that an image, both positive and negative, will affect consumers towards service providers. There is a significant influence on service quality on customer satisfaction at the Siti Khadijah Islamic Hospital in Palembang. This means that the better the quality of service, the patient satisfaction will increase.

There is a significant influence between customer satisfaction variables on customer loyalty at Siti Khadijah
Islamic Hospital in Palembang. This means that patients who are increasingly satisfied will certainly affect their emotions so that the trust formed in patients with the hospital will be strong so that it will increase their loyalty. There is a significant influence between hospital image variables on customer loyalty at Siti Khadijah Islamic Hospital in Palembang. This means that the better the hospital's image, the more trusted the hospital's services will be, thus increasing its loyalty.

There is a significant influence between service quality variables on customer loyalty at the Siti Khadijah Islamic Hospital in Palembang. This means that the greater the quality of services provided by the Siti Khadijah Islamic Hospital in Palembang

\section{CONCLUSIONS}

There is a significant influence between hospital image and service quality on customer loyality through customer satisfaction at the Siti Khadijah Islamic Hospital in Palembang

Future researchers should conduct the same study, with more homogeneous patient samples, for example patients with general patient status and add a larger sample size. In addition, data retrieval should be carried out during the recovery period of the patient, so that the patient is truly ready to provide responses to the questions asked, for example patients who have been declared cured and have been allowed to go home by the doctor.

\section{REFERENCES}

[1] Assauri. 2003. Customer Service yang Baik Landasan Pencapaian Customer Satisfaction dan Usahawan, No. 01 Tahun XXXII. 25-30. Jakarta.

[2] Hatta, Gemala R. 2008. Manajemen Informasi Kesehatan di Sarana Pelayanan Kesehatan. Jakarta: UI Press.

[3] Bloemer, J. Ruyter and Wetzel, M. (1998). On The Relationship Between Perceived Service Quality, Service Loyalty and Switching Cost International Journal of Industry Managemen, 107 (5); 57-62.

[4] Hidajahningtyas, Nurullah. (2013). Pengaruh Citra Poliklinik Eksekutif Rumah sakit Daerah dr. Soebandi Kabupaten Jember. Jurnal Vol XII. No. $1 / 2013$

[5] Barsasella, Diana. 2012. Sistem Informasi Kesehatan. Jakarta: Rineka Cipta.

[6] Griffin, J. (2005). Customer Loyalty: Menumbuhkan dan Mempertahankan Kesetiaan Pelanggan. Jakarta: Erlangga. 
[7] Lupiyoadi, Rambat. (2001). Manajemen Pemasaran Jasa. Jakarta: PT Salemba Empat.

[8] Muhimmah, I., 2016, March. Evaluasi Faktor-Faktor Kesuksesan Implementasi Sistem Informasi manajemen Rumah Sakit di PKU Muhammadiyah Sruweng dengan Menggunakan Metode Hot-Fit. Seminar Nasional Informatika Medis (SNIMed).

[9] Laksana, Fajar. (2008). Manajemen Pemasaran; Pendekatan Praktis. Yogyakarta: Graha Ilmu.

[10] Mohsan, Faizan, et al,. (2011). Impact of Customer Satisfaction on Customer Loyalty and Intentions to Switch: Evidence from Banking Sector of Pakistan. International Journal of Business and Social Science. Vol. 2. No. 16. September 2011. pp.263-270.

[11] Depkes. 2013. Dasar Pembentukan BPJS. Undangundang Nomor 24 Tahun 2011 tentang Badan Penyelenggara Jaminan Sosial dan Undang-undang Nomor 40 Tahun 2004 tentang Sistem Jaminan Sosial Nasional, Pasal 5 ayat (1) dan Pasal 52.

[12] Kemenkes. Kepmenkes RI Nomor 82 tahun 2013, tentang Sistem Informasi Manajemen Rumah Sakit. Jakarta: Kemenkes RI. 2013. 